\title{
ЛЕКСИЧКО-СЕМАНТИЧКИТЕ ОДНОСИ ХИПОНИМИЈА И ХИПЕРОНИМИЈА КАЈ ПРАВНИТЕ ТЕРМИНИ ВО АНГЛИСКИОТ ЈАЗИК СО ПРЕВОДНИ ЕКВИВАЛЕНТИ НА МАКЕДОНСКИ ЈАЗИК
}

\author{
Мери Лазаревска \\ Универзитет „Св. Кирил и Методиј“, Скопје \\ mlazarevska@gmail.com
}

Целта на овој труд е да се испита и да се утврди природата на англискиот јазик на правото преку лексичко-семантичките односи хипонимија и хиперонимија кај правните термини во англискиот јазик и во македонскиот јазик. Од извршената анализа на правните термини во кривичното право може да се заклучи дека правниот вокабулар во англискиот јазик претставува јасно структуриран систем на семантички полиња, кои можеме да ги претставиме преку парадигматските односи на хиперонимија и хипонимија, каде што тргнуваме од архилексемата law 'право', како главен хипероним и многу кохипоними, кои претставуваат хипероними на други хипоними, сѐ до најосновните термини од секое посебно семантичко поле. Терминот taxonym претставува хипоним на терминот 'хипоним'. Системот се карактеризира, главно, со однос part - whole 'дел - целина', што се одржува не само меѓу индивидуалните лексеми и лексичкото поле туку и меѓу специфичните лексички полиња и вокабуларот како целина.

Клучни зборови: англискиот јазик на правото, хиперонимија, хипонимија, семантичко поле, однос дел - целина 


\title{
THE LEXICAL AND SEMANTIC RELATIONS OF HYPONYMY AND HYPERNYMY IN LAW TERMS OF THE ENGLISH LANGUAGE WITH TRANSLATIONAL EQUIVALENTS IN MACEDONIAN
}

\author{
Meri Lazarevska \\ Ss. Cyril and Methodius University, Skopje \\ mlazarevska@gmail.com
}

The goal of this paper is to analyse and understand the nature of the Legal English through the lexical and semantic relations of hyponymy and hypernymy present in the legal terms in English and Macedonian. From the analysis of the legal terms used in the criminal law, it can be concluded that the law vocabulary in English represents a clearly structured system of semantic fields which could be shown through the paradigmatic relations of hyponymy and hypernymy, starting from the archlexeme "law" ('право' in Macedonian), as a main hypernym, and many hyponyms which represent hypernyms of other hyperonyms, all up to the most basic terms in each separate semantic field. The term taxonym represents a hyponym of the term "hyponym". This system is mainly characterised by the part/whole relationship, which holds not only between the individual lexemes and the lexical field, but also between the specific lexical fields and the vocabulary as a whole.

Keywords: legal english, hypernymy, hyponymy, semantic fields, part/whole relationship 


\section{1 Семантичкото поле и хипонимијата}

Односот на хипонимија наспроти хиперонимија наметнува хиерархиска структура на вокабуларот и на одредените лексичко-семантички полиња во рамките на вокабуларот. Теоријата на лексичко-семантичките полиња е воведена од страна на Џост Триер (Jost Trier) во триесеттите години на минатиот век, иако според Џон Лајонс (John Lyons), оваа теорија има историски корени во идеите на Вилхелм фон Хумболт и Јохан Готфрид Хердер. За Лајонс, во 1970-тите, зборовите што се поврзани во какво било значење, припаѓаат на исто семантичко поле. Според Џексон и Амвела, не постојат договорени критериуми за утврдување семантички полиња, иако заедничката компонента на значењето може да биде една (Jackson et al. 2000: 14). Тие велат дека според теоријата на лексичкото поле, вокабуларот на јазикот е динамичен интегриран систем што се состои од лексеми кои се структурирани според значенските односи (Jackson et al. 2000:15). Јазичниот систем континуирано се менува со интеракција меѓу различни процеси, како што се исчезнување на лексеми што постоеле одамна или проширување или стеснување на значењата на некои лексеми. Системот, главно, се карактеризира со однос part/whole 'дел целина', што се одржува не само меѓу индивидуалните лексеми и лексичкото поле туку и меѓу специфичните лексички полиња и вокабуларот како целина.

Лерер ја користи следната дефиниција за семантичко поле: „Семантичкото поле претставува група зборови што се тесно поврзани по нивното значење и често подредени под еден општ термин“ (Lehrer 1974: 22). Дискутирајќи ја теоријата за полињата, Лајонс прави разлика меѓу лексичко и семантичко поле. Тој претпоставува дека теоријата за полињата се занимава со анализа на значењето и ја прави следната дистинкција меѓу лексичкото и семантичкото поле:

Лексемите и другите единици што се семантички поврзани, било парадигматски или синтагматски, во рамките на даден јазичен систем, може да се каже дека припаѓаат на исто семантичко поле, додека полето чии членови се лексемите, претставува лексичко поле. Според тоа, лексичкото поле претставува и парадигматски и синтагматски структурирана подгрупа на вокабуларот (Lyons 1977: 268).

Бринтон (Brinton) го дефинира семантичкото поле или 'семантичкиот домен' и го поврзува со концептот хипонимија (Brinton 2000: 112). Според него, семантичкото поле денотира сегмент од реалноста. Симболизирано е со низа поврзани зборови, кои делат заеднички семантички особености. Зборовите во семантичкото поле не се синоними, но се користат за да зборуваат за еден општ феномен. Значењето на секој збор во едно семантичко поле делумно зависи од неговиот однос со другите зборови во истата концептуална сфера (или област), т.е. во истото семантичко поле. Круз во своите размислувања за хипонимијата обрнува внимание кон терминот taxonym и вели дека овој термин претставува хипоним на терминот 'хипоним'. За да ги тестира таксонимите, поткласа на хипонимите, Круз ја користи следната рамка: $A(n) X$ is a kind of $Y$ ' $\mathrm{X}$ е вид на 
Y' (Cruse 1975: 28). Истата формула ја користи Лајонс за да утврди каков однос е хипонимијата (Lyons 1977: 292) Меѓутоа, тој истакнува дека глаголите, придавките, предлозите и другите делови на говорот не може да се вметнат во оваа формула без претходно да бидат номинализирани (Lynos 1977: 294).

\section{2 Хипонимијата и хиперонимјата во англискиот јазик на правото}

Хиерархиската структура на вокабуларот најдобро се согледува во лексичко-семантичките односи на хипонимија и хиперонимија. Овие односи подразбираат однос на вклученост, кој ги организира термините во таксономски или хиерархиски дијаграми во вид на дрво. Лексичките единици што се дел од дадена таксономија се наоѓаат во релација на генерична или прототипна хипонимија. Една лексема е претставник на повеќе специфични лексеми. Овој семантички однос претставува значенски однос меѓу предикатите, така што значењето на едниот предикат е содржано во значењето на другиот, што значи дека претставува однос 'вид на'. Дефинирањето на хипонимијата во услови на унилатерална импликација ни овозможува да ја дефинираме синонимијата како билатерална или симетрична хипонимија: ако $\mathrm{X}$ е хипоним на $\mathrm{Y}$, a $\mathrm{Y}$ е хипоним на $\mathrm{X}$, тогаш $\mathrm{X}$ и $\mathrm{Y}$ се синоними. Хипонимијата е транзитивен однос. Ако $\mathrm{X}$ е хипоним на $\mathrm{Y}$, а $\mathrm{Y}$ е хипоним на $\mathrm{Z}$, тогаш и $\mathrm{X}$ е хипоним на Z. Така за пропозициите изразени во 'убиството е вид кривично дело', можеме да кажеме дека се аналитички 'секогаш вистинити или изразуваат општи вистини'. Во англискиот јазик на правото би можело да се претпостави дека архилексемата би бил терминот Law, на македонски 'право'. Од овие термини би произлегле, најпрво, сите видови право што постојат, а потоа нивните хипоними, т.е. специфичните поделби според областите на правото, па до најспецифичните кохипоними од определените семантички полиња. Правниот вокабулар во јазиците може да се структурира во семантички полиња, кои, всушност, претставуваат посебни области во правото.

Во нашиов труд најпрвин ќе тргнеме од појавата на хиперонимија и хипонимија при најопштата поделба на правниот вокабулар, а потоа ќе се ограничиме на хипонимијата и хиперонимијата кај правните термини во англискиот јазик во областа на кривичното право. За да ја избегнеме преобемноста при анализата на овие односи, ќе се задржиме, главно, на најспецифичните именки, носители на идиосинкретското правно значење, кои се појавуваат како хипероними и хипоними во областа на англискиот јазик во кривичното право. На тој начин ќе се добие прегледност за структурираноста на правниот вокабулар во англискиот и во македонскиот јазик и ќе се изведат заклучоци за особеностите на правните термини во двата јазика. Ќе ја разгледаме поврзаноста меѓу синонимијата и хипонимијата, како и можноста или неможноста правните термини да ги сместиме во споменатите рамки на унилатерална импликација и симетрична синонимија. Се надеваме дека оваа анализа ќе покаже дали и колку правниот вокабулар во англискиот и во македонскиот јазик може да се издиференцира како јасно структуриран систем и дали еквивалентите од англискиот во македонскиот јазик прет- 
ставуваат хипоними или кохипоними на истиот термин што се појавува како хипероним во англискиот јазик.

Табела 1. Англиската архилексема law и нејзините хипоними

\begin{tabular}{|c|c|c|c|c|c|c|c|}
\hline \multicolumn{9}{|c|}{ LAW } \\
\hline \multicolumn{3}{|c|}{ PUBLIC LAW } & \multicolumn{7}{c|}{ PRIVATE LAW } \\
\hline $\begin{array}{c}\text { Ciminal } \\
\text { Law }\end{array}$ & $\begin{array}{c}\text { Constitutional } \\
\text { law }\end{array}$ & $\begin{array}{c}\text { Interna- } \\
\text { tional law }\end{array}$ & Tort & Contract & Trust & Probate & $\begin{array}{c}\text { Family } \\
\text { Law }\end{array}$ \\
\hline
\end{tabular}

Табела 1а. Преводни еквиваленти на термините во табела 1 во македонскиот јазик

\begin{tabular}{|c|c|c|c|c|c|c|c|}
\hline \multicolumn{5}{|c|}{ ПРАВО } \\
\hline \multicolumn{3}{|c|}{ ЈАВНО ПРАВО } & \multicolumn{5}{c|}{ ПРИВАТНО ПРАВО } \\
\hline $\begin{array}{c}\text { Кривично } \\
\text { паво }\end{array}$ & $\begin{array}{c}\text { Уставно } \\
\text { право }\end{array}$ & $\begin{array}{c}\text { Меѓуна- } \\
\text { родноправо }\end{array}$ & $\begin{array}{c}\text { Граѓански } \\
\text { деликт }\end{array}$ & Договор & $\begin{array}{c}\text { Довери- } \\
\text { телство }\end{array}$ & $\begin{array}{c}\text { Оставинска } \\
\text { постапка }\end{array}$ & $\begin{array}{c}\text { Семејно } \\
\text { право }\end{array}$ \\
\hline
\end{tabular}

Во табелите 1 и 1а тргнуваме од терминот Law како најопшт термин во правната терминологија, или главен хипероним. Од него произлегуваат подредените термини, 'хипоними', кои се однесуваат на најопштата поделба на правото во Англија и Велс.

\section{3 Лексичко-семантичките односи хипонимија и хиперонимија во кривичното право во англискиот јазик}

Табела 2. Англискиот термин criminal law и неговите хипоними

\begin{tabular}{|c|c|c|}
\hline \multicolumn{3}{|l|}{ CRIMINAL LAW } \\
\hline \multicolumn{3}{|l|}{ CRIMINAL TRIAL } \\
\hline \multicolumn{3}{|l|}{ PARTIES } \\
\hline PROSECUTOR & DEFENDANT & LAWYER \\
\hline \multicolumn{3}{|l|}{ CRIMES/OFFENCES } \\
\hline \multicolumn{3}{|l|}{ VERDICT } \\
\hline \multicolumn{3}{|l|}{ SENTENCE/PUNISHMENT } \\
\hline DEFENSE & & \\
\hline
\end{tabular}

Табела 2а. Преводни еквиваленти на термините во табела 2 во македонскиот јазик

\begin{tabular}{|l|l|}
\hline \multicolumn{2}{|l|}{ КРИВИЧНО ПРАВО } \\
\hline КРИВИЧНА ПОСТАПКА \\
\hline СТРАНКИ & \multicolumn{2}{l|}{} \\
\hline ОБВИНИТЕЛ & ОБВИНЕТ \\
\hline КРИВИЧНИ ДЕЛА/ПРЕКРШОЦИ & \multicolumn{2}{l|}{} \\
\hline ПРЕСУДА & \multicolumn{2}{l|}{} \\
\hline КАЗНА & \\
\hline ОДБРАНА & \\
\hline
\end{tabular}


Во табелите 2 и 2а го разгледуваме првиот хипоним од третото ниво на табелата 1, 'criminal law'. Терминот претставува хипероним на сите термини што се наведени во табелата 2. Секоја следна табела претставува генерично разложување на дадените термини, кои во почетните табели се наоѓале во својство на хипоним, а во понатамошните табели се појавуваат во својство на хипероними, со свои понатамошни хипоними. Терминот criminal law ‘кривично право' претставува главен хипероним во табелите 2 и 2а, а од него следува хипонимот criminal trial 'кривична постапка', кој е хипероним на терминот party 'странка', a, пак, party 'странка' претставува хипероним на хипонимите prosecutor 'обвинител', defendant 'обвинет' и lawyer 'адвокат'. Во кривичната постапка тие решаваат кривични дела или прекршоци и за нив носат verdict 'пресуда', sentence/punishment 'казна' и решаваат спорови по определена одбрана defense.

Табела 3. Англискиот термин criminal trial и неговите хипоними

\begin{tabular}{|l|l|l|}
\hline CRIMINAL TRIAL \\
\hline PARTY & DEFENDANT & LAWYER \\
\hline PROSECUTOR & offender & Barrister \\
\hline District Attorney & criminal & Solicitor \\
County Attorney & Attorney \\
State's Attorney & felon & \\
Federal District Attorney &
\end{tabular}

Табела 3а. Преводни еквиваленти на термините во табела 3 во македонскиот јазик

\begin{tabular}{|l|l|l|}
\hline \multicolumn{2}{|l|}{ КРИВИЧНА ПОСТАПКА } \\
\hline СТРАНКА & ОБВИНЕТ & АДВОКАТ \\
\hline ОБВИНИТЕЛ & прекршител & $\begin{array}{l}\text { АДвокат од повисок ранГ } \\
\text { во Англија }\end{array}$ \\
\hline Областен обвинител & Адвокат од понизок ранг \\
Дколиски обвинител & кржавен обвинител & во Англија \\
Федерален обвинител & Адвокат во Америка \\
\hline
\end{tabular}

Во табелите 3 и 3а продолжуваме со првиот хипоним од табелите 2 и 2 а и го анализираме терминот criminal trial, кој претставува хипероним на хипонимот party, кој, пак, е хипероним на хипонимите prosecutor, defendant, lawyer. Тие се во лексичко-семантички однос на генерична хипонимија, а самите имаат свои хипоними, кои се претставени во третото ниво на табела 3. Така, терминот prosecutor 'обвинител' е хипероним на District Attorney 'околиски обвинител' (во Америка), County Attorney 'областен обвинител’ (во Америка), State's Attorney 'државен обвинител' (во Америка), Federal District Attorney ‘федерален обвинител' (во Америка), кои се кохипоними, но и приближни синоними, што се употребуваат во американското говорно подрачје.

Терминот prosecutor ce употребува со исто значење и во американското и во англиското говорно подрачје, т.е. со значењето 'обвинител'. Како што 
можеме да забележиме, за терминот 'обвинител' во американското говорно подрачје постојат повеќе термини, зависно од тоа каде ја врши обвинителот својата функција. Во македонскиот јазик постои само еден термин како преводен еквивалент за сите.

Терминот defendant 'обвинет' е хипоним на хиперонимот party 'странка', но е и хипероним на термините criminal 'криминалец', offender 'престапник', felon 'тежок криминалец', кои, пак, претставуваат синоними и се наоѓаат во лексичко-семантички однос на билатерална или симетрична хипонимија. Offender е хипоним на criminal; criminal е хипоним на offender, што значи дека тие се синоними. Во истиот пример се согледува хипонимијата како транзитивен однос. Во македонскиот јазик сите три термини можеме да ги преведеме со терминот 'криминалец', што значи дека зборуваме за комплетна синонимија. Единствено, терминот felon претставува степенуван синоним на criminal, бидејќи felon е лице што сторило тешко кривично дело, a criminal е лице што сторило какво и да е кривично дело.

Терминот lawyer 'адвокат' е хипоним на хиперонимот party 'странка', иако можеме да кажеме дека не е директен хипоним, бидејќи страните на спорот секогаш се prosecutor 'обвинител' и defendant 'обвинет'. Но, бидејќи адвокатот секогаш ја застапува странката во кривичната постапка и него го ставаме во кохипонимите на терминот party 'странка'. Од друга страна, самиот термин lawyer 'адвокат' претставува хипероним на термините barrister, solicitor и attorney, кои се наоѓаат во транзитивен однос со lawyer и се приближни синоними. Термините barrister и solicitor се користат во британскиот англиски јазик и се преведуваат со 'адвокат', но нивната семантика е различна, бидејќи тие имаат различна функција во правниот систем на Англија и на Велс. Токму поради тоа, терминот solicitor претставува лексичка празнина во нашиот јазик, затоа бараме приближно лексичко решение за да го преведеме. Терминот attorney се користи во американското јазично подрачје и е синоним на barrister и solicitor, а ги врши и двете функции и на barrister и на solicitor. И во нашиот правен систем адвокатот ги врши двете функции.

Табела 4. Англискиот термин crime и неговите хипоними

\begin{tabular}{|l|l|l|l|l|l|l|}
\hline \multicolumn{1}{|l|}{ CRIMES = OFFENCES } & Misdemeanor & $\begin{array}{l}\text { 1. Crimes against } \\
\text { persons }\end{array}$ & $\begin{array}{l}\text { 2. Crimes } \\
\text { against } \\
\text { property }\end{array}$ & $\begin{array}{l}\text { 3. In- } \\
\text { choate } \\
\text { crimes }\end{array}$ & $\begin{array}{l}\text { 4. Crimes } \\
\text { against justice }\end{array}$ \\
\hline $\begin{array}{l}\text { Petty offence: } \\
\text { - pick pocketing; } \\
\text { - pilfering; } \\
\text { - shoplifting }\end{array}$ & Battery & $\begin{array}{l}\text { Bodily } \\
\text { harm }\end{array}$ & $\begin{array}{l}\text { Abduc- } \\
\text { tion/ } \\
\text { Kidnap- } \\
\text { ping }\end{array}$ & $\begin{array}{l}\text { Identity } \\
\text { theft }\end{array}$ & Rape & Homicide \\
\hline \begin{tabular}{l|l|l|l|l|} 
1. Crimes against persons \\
Assault
\end{tabular}
\end{tabular}




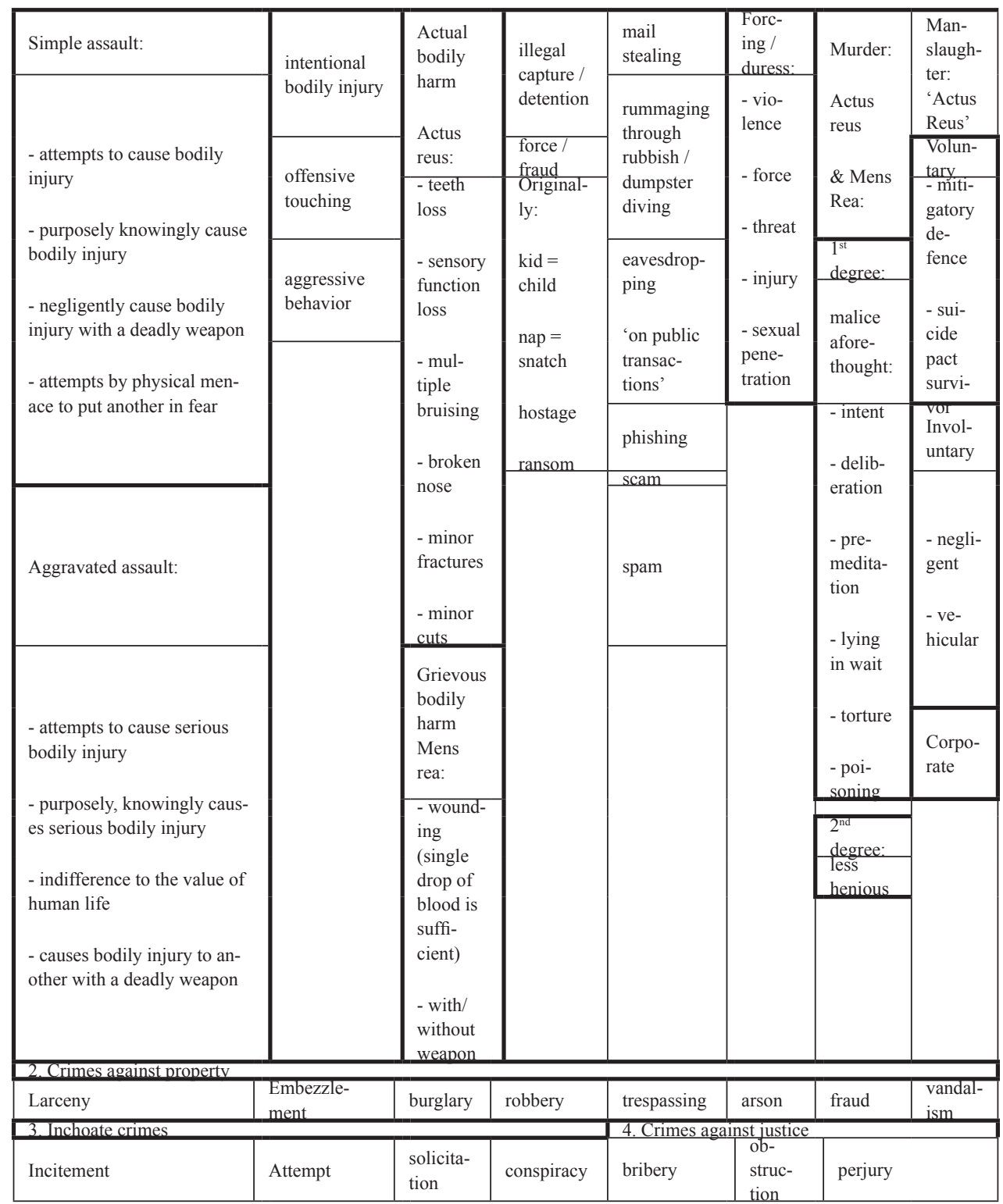




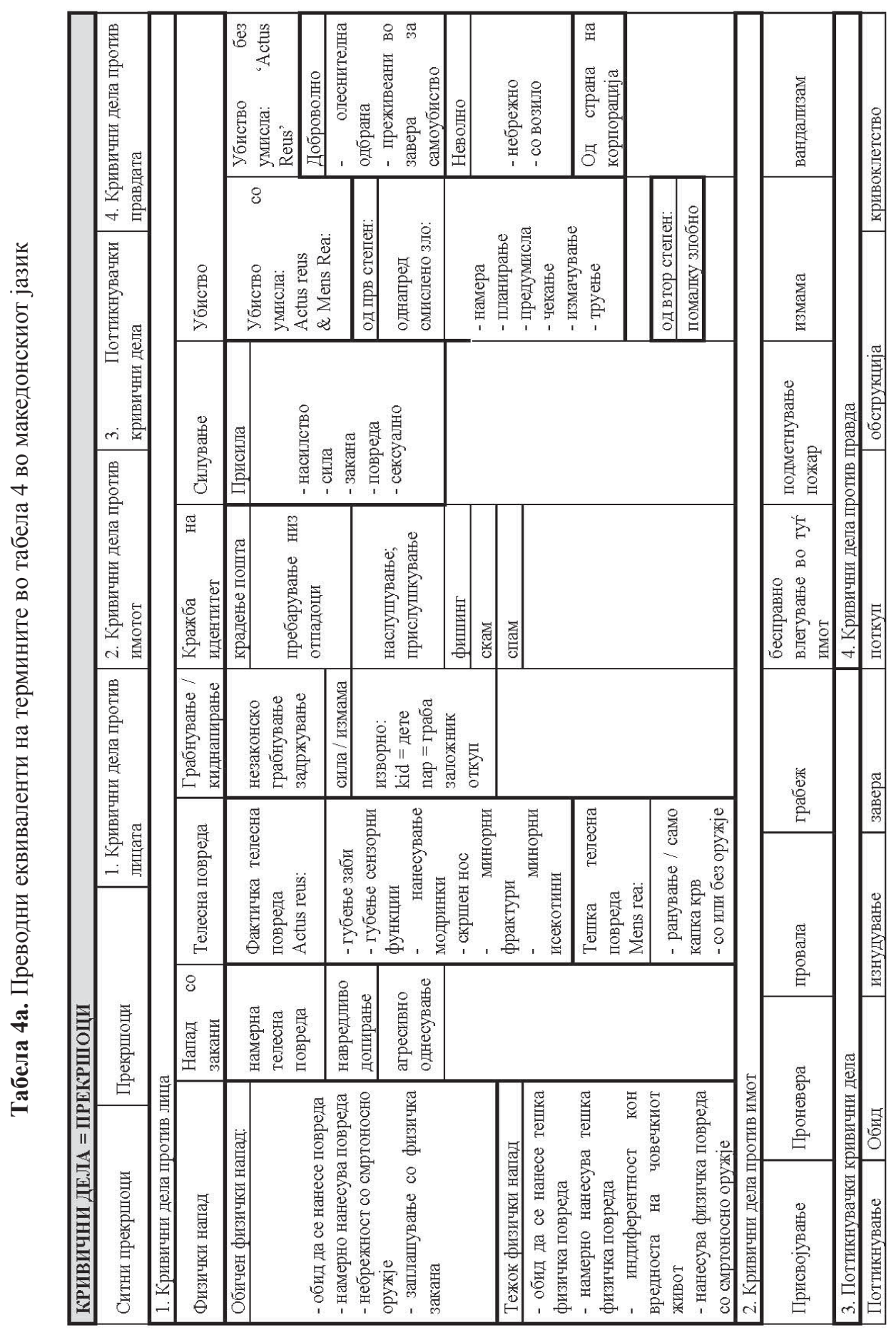


Во табелите 4 и 4а терминот crime 'кривично дело', синоним на 'offence' се појавува како главен хипероним, чии директни хипоними се претставени во второто ниво на табелата. Првиот хипоним petty offences 'ситни прекршоци' не е обележан со број, како и вториот misdemeanor 'прекршок', од причина што основната поделба на типовите на кривични дела во англиската терминологија е на четири типа: 1. Crimes against persons 'кривични дела против лицата'; 2. Crimes against property 'кривични дела против имотот'; 3. Inchoate crimes 'поттикнувачки кривични дела'; 4. Crimes against justice 'кривични дела против правдата'. Пред да пристапиме кон нивната анализа, најпрвин треба да го објасниме терминот misdemeanor, што се преведува како 'прекршок', но и сите други кривични дела можат да се наречат прекршоци. Карактеристично за misdemeanor е тоа што овој термин се однесува на видови прекршоци за кои во англискиот јазик не постојат определени термини, а, сепак, се однесува на потешки кривични дела.

Под хиперонимот crimes against persons 'кривични дела против лицата' се вклучени кохипонимите assault 'физички напад', battery 'напад со закани и сила', bodily harm 'телесна повреда', abduction/kidnapping 'грабнување'/'киднапирање', identity theft 'кражба на идентитет', rape 'силување' и homicide 'убиство'. Понатаму тие претставуваат хипероними на други термини, кои подоцна се појавуваат како хипероними, сѐ додека не се покаже и последното ниво на хипонимија.

Терминот assault ‘физички напад’ претставува хипероним на кохипонимите simple assault 'обичен физички напад' и aggravated assault 'тежок физички напад’, кои се наоѓаат во однос на генеричка хипонимија со нивниот хипероним, а, од друга страна, се појавуваат како хипероними на бројни изрази што го појаснуваат нивното значење, чии клучни зборови можат да се категоризираат како хипоними на simple assault 'обичен физички напад' и aggravated assault 'тежок физички напад'.

Поврзани, овие хипоними го даваат значењето на хипероним, кој со употреба на смртоносно оружје претставува индиферентност кон вредноста на човековиот живот.

Во англиската терминологија на правото, терминот battery 'напад со закани' се смета за приближен синоним на терминот assault и двата термина многу често се користат за ист вид кривично дело, со тоа што battery 'напад со закани', дополнително на intentional bodily injury 'намерна телесна повреда', вклучува offensive touching 'навредливо допирање', како и violent behavior 'агресивно однесување'.

Хиперонимот bodily harm 'телесна повреда' ги содржи хипонимите actual bodily harm 'фактичка телесна повреда' и grievous bodily harm 'тешка телесна повреда'. Во хипонимите на овие два термина за првпат ги среќаваме термините од латинско потекло actus reus и mens rea, кои во англиската терминологија на правото претставуваат важни елементи на кривичните дела. Actus reus во англискиот јазик се преведува co guilty act 'виновен акт или дело', додека mens rea се преведува co guilty mind 'виновен ум' или 'виновна свест'. Actus reus е присутен во сите кривични дела, додека mens rea треба да се докаже. За нив подетално ќе дообјасниме кога ќе зборуваме за кривичното дело homicide 'убиство'. 
Термините abduction 'грабнување' и kidnapping 'киднапирање', како хипероними, ги сместивме на исто рамниште, бидејќи тие се приближни синоними и се наоѓаат во однос на унилатерална импликација во однос на своите заеднички елементи - кохипоними: illegal capture, detention, force, fraud и hostage. Единствениот хипоним по кој тие се разликуваат е ransom 'откуп', кој е присутен кај kidnapping 'киднапирање' и претставува основен услов грабнувањето да се смета за киднапирање.

Терминот identity theft се појавува како хипероним на следниве хипоними: mail stealing 'крадење пошта', dumpster diving 'пребарување низ отпадоци', eavesdropping 'наслушување; прислушување', phishing, scam, spam. Овие хипоними се наоѓаат во релација на генерична хипонимија (сите тие претставуваат вид или начин на кражба на идентитет). Интересно е да обрнеме внимание на термините spam, scam и phishing. Во македонскиот јазик овие термини претставуваат лексички празнини, немаат свој преводен еквивалент во македонскиот јазик и најчесто ги употребуваме со нивниот оригинален израз на англиски јазик. Наредниот термин на третото ниво од табелите 4 и 4 a rape 'силување' претставува хипероним на хипонимите duress 'присила' и forcing 'присилување', кои се приближни синоними, со тоа што 'duress' во својата семантика го содржи елементот forcing 'примена на сила'. Овој термин се јавува и како хипероним на хиппонимите: violence 'насилство', force 'сила', threat 'закана', injury 'повреда', sexual penetration 'сексуално пенетрирање'.

Терминот homicide 'убиство' претставува комплексен хипероним, бидејќи ги содржи хипонимите murder и manslaughter, а тие се хипероними на хипоними што го појаснуваат нивното значење. Имено, и терминот $m u r d e r$ и терминот manslaughter за преводен еквивалент во македонскиот јазик го имаат терминот 'убиство'. Но, постои разлика во нивната семантика, која е, всушност, објаснета со нивните хипоними во табелите 4 и 4а. Како што споменавме, термините од латинско потекло actus reus и mens rea претставуваат важни елементи на кривичните дела и зависно од нивното присуство или отсуство, делото се смета за потешко или полесно кривично дело. Како што можеме да забележиме во табелите 4 и $4 \mathrm{a}$, под терминот murder стојат хипонимите actus reus и mens rea, што значи дека двата елемента се присутни при овој тип убиство. Терминот malice aforethought, како хипоним на хиперонимот mens rea 'guilty mind' - 'виновен ум' или 'свест', се појавува како хипероним на intent 'намера', deliberation 'размислување', premeditation 'предумисла', lying in wait 'чекање', 'начекување', torturing 'измачување', poisoning 'труење'. Сите овие термини го објаснуваат хиперонимот murder и од нив можеме да заклучиме дека murder се преведува како 'убиство со умисла'. За повеќето кривични дела криминалецот се прогласува за виновен ако сторил кривично дело (кога елементот actus reus е присутен) или бил во специфична ментална состојба, со намера да изврши кривично дело (кога елементот mens rea е присутен).

Терминот 'manslaughter' како хипероним го содржи хипонимот actus reus, како неизоставен елемент на кривичното дело, но за разлика од murder, во него не е присутен елементот mens rea, што нѐ наведува на заклучок дека manslaughter е вид убиство, но без умисла. Токму затоа овој термин се пре- 
ведува како 'убиство без умисла'. Понатаму, убиството без умисла може да биде и неволно или претставено со хипонимот involuntary, кој се појавува како хипероним на термините negligent 'небрежно' и vehicular 'со возило'. На тој начин manslaughter би го протолкувале како 'убиство од небрежност', или 'убиство при сообраќајна незгода'.

Последниот тип убиство без умисла во англиската терминологија на правото е corporate manslaughter, што би го протолкувале како убиство без умисла од страна на работната организација каде што работел убиениот.

\section{4 Лексичко-семантичките односи хипонимија и хиперонимија кај називите на судовите во англискиот јазик}

Судскиот систем во Англија и Велс многу се разликува од судскиот систем во Македонија. Токму затоа можеме да кажеме дека е тешко да се пронајдат точни преводни еквиваленти на имињата на судовите и тие претставуваат лексички празнини во македонскиот јазик. Од друга страна, американскиот судски систем, според хиерархијата на судови и нивните називи, повеќе наликува на македонскиот систем, но таа сличност е само терминолошка. Во американскиот судски систем, како и во македонскиот, постојат три нивоа на судска хиерархија и нивната најопшта поделба е на првостепен, второстепен (или апелациски) и врховен суд. Но, во Америка постојат уште две нивоа: државно и федерално, па според тоа и називите на судовите се разликуваат:

Табела 5. Англискиот термин court (во Америка) и неговите хипоними

\begin{tabular}{|c|c|c|}
\hline $\begin{array}{c}\text { Level1 } \\
\text { Trial Court }\end{array}$ & $\begin{array}{c}\text { Level2 } \\
\text { Appellate }\end{array}$ & $\begin{array}{c}\text { Level 3 } \\
\text { Court of Last Resort }\end{array}$ \\
\hline $\begin{array}{c}\text { State system: } \\
\text { Circuit Court }\end{array}$ & Court of Appeals (of a State) & Supreme Court (of a State) \\
\hline $\begin{array}{c}\text { Federal System: } \\
\text { District Court }\end{array}$ & U.S. Court of Appeals & U.S. Supreme Court \\
\hline
\end{tabular}

Со оглед на тоа дека судските системи во земјите се различни, ние би можеле да дадеме најопшти преводни еквиваленти, со приближни терминолошки определби, но никако не би смееле да ги изедначуваме типовите судови, колку и да звучат еднакво во двата јазици, бидејќи правните системи во земјите во англиското јазично подрачје се разликуваат од правниот систем што потекнува од римското право, од кое потекнува македонскиот правен систем. Можниот превод на типовите судови во Америка би бил следниот:

Табела 5а. Преводни еквиваленти на термините во табела 5а на македонски јазик

\begin{tabular}{|l|l|l|}
\hline $\begin{array}{l}\text { Ниво 1 } \\
\text { Основен суя }\end{array}$ & $\begin{array}{l}\text { Ниво 2 } \\
\text { Айелациски суя }\end{array}$ & $\begin{array}{l}\text { Виво 3 } \\
\text { Врховен суя }\end{array}$ \\
\hline $\begin{array}{l}\text { Државен систем: } \\
\text { Окружен суд }\end{array}$ & $\begin{array}{l}\text { Апелациски суд } \\
\text { (на држава) }\end{array}$ & Врховен суд (на држава) \\
\hline $\begin{array}{l}\text { Федерален систем: } \\
\text { Областен суд }\end{array}$ & Апелациски суд на САД & Врховен суд на САД \\
\hline
\end{tabular}


Од табелата 5а можеме да забележиме дека за терминот trial court одбравме преводен еквивалент кој најмногу одговара на нашата терминолошка определба за првостепениот суд во Македонија - основен суд, за второстепениот и за третостепениот суд најопштите терминолошки определби се исти како во Македонија, но веќе кај нивните хипоними значењето се разликува. Пред сѐ, Америка е земја со федерално уредување и затоа постојат судови на државно и на федерално ниво. Најголемата замка кај овие термини претставува терминот supreme court 'врховен суд', кој, како што е даден во табелата, е најраспространет во сите американски држави, освен во државата Њујорк и градот Њујорк, каде што supreme court претставува првостепен суд, а споровите завршуваат во Appellate Court 'апелациски суд' како највисок суд во државата. Потребно е да се знае овој факт, бидејќи има голема разлика во тоа дали споровите започнуваат (доколку се во првостепен суд) или завршуваат (доколку се во врховен суд).

\section{5 Заклучок}

Од извршената анализа на лексичко-семантичките односи хиперонимија и хипонимија кај правните термини во кривичното право, можеме да заклучиме дека правниот вокабулар во англискиот јазик претставува јасно структуриран систем на семантички полиња, кои можеме да ги претставиме преку парадигматските односи на хиперонимија и хипонимија, каде што постојат хипероними - надредени термини и многу кохипоними, кои понатаму претставуваат хипероними на други хипоними, сѐ до најосновните термини од секое посебно семантичко поле. Хипонимите најчесто се наоѓаат во релација на генерична или прототипна хипонимија со своите хипероними, изразени преку таканаречениот однос „вид на“, и на овој начин разбираме дека една лексема е хипоним на друга лексема или дека две лексеми претставуваат кохипоними. Во рамките на хипонимијата и хиперонимијата, како лексичко-семантички однос, исто така утврдивме дека правните термини во англискиот јазик влегуваат во односи на унилатерална импликација или симетрична хипонимија, каде што хипонимите претставуваат синоними. Оваа појава е присутна во англискиот јазик на правото, но не е толку честа како појавата на генерична хипонимија.

\section{Библиографија}

Камбовски, В., Мицајков М. И Бајалџиев, Д. (2007). Филозофија на йравойо. Скопје: Правен факултет „Јустинијан Први“.

Atkinson, J.M. and Drew, P. (1979). Order in Court. London: Macmillan.

Cruse, D.A. (1986). Lexical Semantics. Cambridge: Cambridge University Press.

Crystal, D. (1991). A Dictionary of Linguistics and Phonetics. Oxford: Blackwell Publishers. Douglas, D. (2000). Assessing Languages for Specific Purposes. Cambridge: Cambridge University Press.

De Bray,R., Dimitrovski,T., Korubin, B., Stamatoski, T., Hill,P., Mircevska, S. and Windle,K (eds.). (1998). Routhledge Macedonian - English Dictionary. London: Routhledge. 
Duranti, A. (2001). Key Terms in Language and Culture. Oxford: Blackwell.

Empson, W. (1965). Seven Types of Ambiguity. Harmondsworth: Penguin.

Fromkin, V. and Rodman, R. (1993). An Introduction to Language. New York:

Harcourt Brace-Jovanovich.

Fromkin, V., Rodman R. and Hyams N. (2000). Linguistics. An Introduction to Linguistic Theory. Oxford: Blackwell.

Garner, B.A. (1987). A Dictionary of Modern Legal Usage. Oxford: Oxford University Press.

Ghadessy, M. (ed.). (1988). Registers of Written English: Situational Factors and Linguistic features. London: Pinter.

Goshgarian, G. (ed.). (1995). Exploring Language. New York: Harper Collins College Publisher.

Hutchison, T. and Waters, A. (1987). English for Specific Purposes. Cambridge: Cambridge University Press.

Hurford, J. R. and Heasley, B. (1983). Semantics: A Coursebook. Cambridge: Cambridge University Press.

Jackson, H. and Amvela, Ze E. (2000). Words, Meaning and Vocabulary. Bloomsbbury Publishing

Kennedy, C. and Rod, B. (1984). English for Specific Purposes. London: Macmillan.

Kooij, G.J. (1971). Ambiguity in Natural Language. Amsterdam: North-Holland Publishing Company.

Lehrer, A. (1974). Semantic Fields and Lexical Structure. Amsterdam: North-Holland Publishing Company.

Lyons, J. (1977). Semantics. Vol. 1. Cambridge: Cambridge University Press.

Martin, E. (ed.). (1997). A Dictionary of Law. Fourth Edition. Oxford: Oxford University Press.

Master, P. and Brinton, M. D. (ed.). (1998). New Ways in English for Specific Purposes.

Alexandria VA: TESOL.

Powel, R. (1993). Law Today. Harrow: Addison Wesley Longman Limited.

Riley, A. (1991). English for Law. London and Basingstoke: Macmillan Publishers Ltd.

Tomic, Mišeska O. (1995). The English Word. Novi Sad: Futura.

Tomić, Mišeska O. and Misic, M. (1994). English Macedonian Dictionary. Skopje: Kultura.

Widdowson, H. (1979). Explorations in Applied Linguistics. Oxford: Oxford University Press.

Cambridge Professional English - International Legal English - Online Legal English Research. http://cdextras.cambridge.org/

EurLex - The access to European Union Law. http:// eur-lex.europa.eu/

Find Law - http://findlaw.com/

Random House Webster's Electronic Dictionary. https://books.google.mk/books/about/ Random_House Webster_s_Unabridged Dictio.html?id=oMfXPwAACAAJ\&redir $\underline{\mathrm{esc}=\mathrm{y}}$

Trans Legal - The world's leading provider of Legal English - CUP. http:// translegal.com/ WordNet - A lexical database for the English Language, Science Laboratory, Princeton, N.J.: Princeton University. http://wordnet.com/ 